\title{
PENETAPAN KUALIFIKASI DESA TERTINGGAL UNTUK PERENCANAAN PROYEK KONSTRUKSI
}

\author{
Winny Augustine ${ }^{1}$ dan Basuki Anondho ${ }^{2}$ \\ ${ }^{1}$ Program Studi Sarjana Teknik Sipil, Universitas Tarumanagara, Jl. Letjen S. Parman No.1 Jakarta \\ Email: winnyaugustine3@gmail.com \\ ${ }^{2}$ Program Studi Sarjana Teknik Sipil, Universitas Tarumanagara, Jl. Letjen S. Parman No.1 Jakarta \\ Email: basukia@ft.untar.ac.id
}

\begin{abstract}
ABSTRAK
Pembangunan daerah tertinggal penting untuk mengurangi kesenjangan wilayah, daerah rawan bencana, serta meningkatkan kualitas lingkungan perumahan dan permukiman dan cakupan pelayanan dasar bidang pekerjaan umum dan permukiman untuk mewujudkan kesejahteraan rakyat yang berkeadilan dan inklusif. Pembangunan daerah tertinggal tidak hanya meliputi aspek ekonomi, tetapi juga aspek sosial, budaya, dan keamanan (bahkan menyangkut hubungan antara daerah tertinggal dengan daerah maju). Sebelum pelaksanaan proyek dimulai ada baiknya dilakukan perencanaan terlebih dahulu yaitu dalam hal ini adalah penetapan kualifikasi daerah tertinggal. Setelah menetapkan kualifikasi daerah tertinggal, maka pengambilan keputusan untuk mengembangkan daerah tersebut dapat dilakukan dengan baik. Tujuan dari penelitian ini adalah menetapkan suatu model sederhana sebagai masukan alternatif penetapan desa tertinggal melalui penyederhanaan variabel. Penelitian ini mengembangkan model dari Kemen DPDTT dan menggunakan data Badan Pusat Statistik (BPS) dan Google Maps. Digunakannya data Google Maps berdasarkan studi literatur jurnal tentang dan dikarenakan terdapat data yang tidak tersedia dalam BPS. Melalui uji hipotesis mean sampel ganda yaitu Uji t Sampel Independen, menunjukkan bahwa model perhitungan yang telah disederhanakan ini dapat digunakan sebagai penetapan kualifikasi desa tertinggal. Sebagai hasil, desa-desa pada sampel populasi yang termasuk dalam kategori desa tertinggal adalah desa Tubuhue, desa Baturaja, kelurahan Bon Kawir, desa Tudi, desa Sambori, desa Air Periukan, desa Tobolang.
\end{abstract}

Kata kunci: pengembangan model, daerah tertinggal, google maps

\section{PENDAHULUAN}

Pembangunan daerah tertinggal merupakan upaya terencana untuk mengubah suatu daerah yang dihuni oleh komunitas dengan berbagai permasalahan sosial ekonomi dan keterbatasan fisik, menjadi daerah yang maju dengan komunitas yang kualitas hidupnya sama atau tidak jauh tertinggal dibandingkan dengan masyarakat Indonesia lainnya. Pembangunan daerah tertinggal ini berbeda dengan penanggulangan kemiskinan dalam hal cakupan pembangunannya. Pembangunan daerah tertinggal tidak hanya meliputi aspek ekonomi, tetapi juga aspek sosial, budaya, dan keamanan (bahkan menyangkut hubungan antara daerah tertinggal dengan daerah maju) (Lubis, 2018). Hal ini menjadi penting untuk mengurangi kesenjangan wilayah, daerah rawan bencana, serta meningkatkan kualitas lingkungan perumahan dan permukiman dan cakupan pelayanan dasar bidang pekerjaan umum dan permukiman untuk mewujudkan kesejahteraan rakyat yang berkeadilan dan inklusif (Priadi, 2016).

Sebelum pelaksanaan proyek dimulai ada baiknya dilakukan perencanaan terlebih dahulu. Perencanaan konstruksi adalah kegiatan mendasar dan menantang dalam manajemen dan pelaksanaan proyek konstruksi. Ini melibatkan pilihan teknologi, definisi tugas kerja, estimasi sumber daya yang diperlukan dan durasi untuk tugas individu, dan identifikasi setiap interaksi antara tugas kerja yang berbeda. Rencana konstruksi yang baik adalah dasar untuk mengembangkan anggaran dan jadwal kerja (Hendrickson, 2008). Dalam merencanakan pembangunan daerah tertinggal perlu diketahui kualifikasi dari daerah tertinggal tersebut terlebih dahulu. Setelah menetapkan kualifikasi daerah tertinggal, maka pengambilan keputusan untuk mengembangkan daerah tersebut dapat dilakukan dengan baik.

Peraturan Menteri Desa, Pembangunan Daerah Tertinggal, dan Transmigrasi Republik Indonesia nomor 3 Tahun 2016 tetang petunjuk teknik penentuan indikator dalam penentuan daerah tertinggal secara nasional menyebutkan perekonomian masyarakat, sumber daya manusia, sarana dan prasarana, kemampuan keuangan 
daerah, aksesibilitas, dan karakteristik daerah sebagai kriteria penetapan daerah tertinggal yang kemudian dijabarkan menjadi 33 variabel penentu penetapan daerah tertinggal.

Amado, et al, (2018) menyatakan masalah dalam menentukan perbatasan wilayah desa dan perkotaan adalah situasi di mana semua informasi dasar (populasi penduduk, infrastruktur yang ada, dan keberadaan fasilitas publik) yang diperlukan untuk menggunakan metode pembatasan saat ini tidak tersedia atau tidak sesuai, proses perencanaan dapat dikompromikan. Dalam situasi ini, perlu diciptakan metode alternatif yang memungkinkan pembatasan batas perkotaan dan pedesaan untuk menetapkan kondisi pembangunan sesuai dengan batas-batas ini dan memastikan pengembangan wilayah yang benar dan efisien.

Dimulyo (2009) menyatakan bahwa masalah dalam menentukan kualifikasi desa tertinggal adalah data statistik kemiskinan berdasarkan survei hanya mewakili sampai tingkat wilayah administrasi tertentu di Indonesia. Berbagai upaya telah dilakukan untuk dapat memprediksi kemiskinan sampai tingkat administrasi yang lebih kecil. Sebenarnya metoda statistik dan survei dapat dikembangkan untuk mendapatkan data kemiskinan sampai wilayah desa, yaitu dengan cara melakukan survei rumah tangga yang representatif di tingkat desa. Namun dengan jumlah desa di Indonesia yang hampir 70.000, survei semacam ini akan sangat besar dan sangat mahal untuk dilaksanakan.

Ferreira dan Condessa (2012) menyatakan perkembangan area perkotaan yang tidak terkontrol dengan karakteristik kepadatan rendah, tersebar, dan berdampak lingkungan dan sosial sedang terjadi di wilayah Eropa terutama di pinggiran kota. Maka dari itu diperlukan suatu metode dalam menentukan wilayah ekspansi, agar lahan yang digunakan dapat semaksimal mungkin.

Banyak cara telah ditemukan oleh pemerintah maupun non-pemerintah dalam menetapkan kualifikasi desa, tetapi cara yang ditemukan mengunakan cara yang sulit dimengerti. Kendala lainnya adalah mengharuskan turun langsung untuk survei lapangan, cara ini dapat memakan waktu yang lama dan juga biaya yang besar dalam proses pengumpulan datanya. Maka dari itu, tujuan dari penelitian ini adalah menetapkan suatu model sebagai masukan alternatif penetapan desa tertinggal dengan menyederhanakan model penetapan kualifikasi desa tertinggal dari model Kemen DPDTT untuk perencanaan proyek infrastruktur di wilayah pedesaan di Indonesia agar proses penetapan tidak memakan waktu yang lama dan biaya yang besar sehingga perencanaan pembangunan proyek dilakukan secara tepat dan dapat meningkatkan kualitas lingkungan hidup masyarakat pedesaan.

\section{STUDI LITERATUR}

Berikut adalah studi literatur yang digunakan pada penelitian ini:

\section{Peraturan Menteri Desa Nomor 3 Tahun 2016}

Berdasarkan Kementrian Pembangunan Daerah Tertinggal tentang petunjuk teknik penentuan indikator dalam penentuan daerah tertinggal secara nasional penetapan daerah dengan kategori tertinggal didasarkan pada perhitungan 6 (enam) kriteria yang meliputi perekonomian masyarakat, sumber daya manusia setempat, ketersediaan infrastruktur (prasarana), kapasitas yang dimiliki daerah / kemampuan keuangan daerah, aksesibilitas, dan karakteristik daerah yang kemudian dijabarkan menjadi 27 variabel penentu penetapan daerah tertinggal.

Dalam menentukan arah ketertinggalan suatu daerah diukur berdasarkan indeks komposit positif dan negatif yang nilainya diantara +1 (positif satu) dan -1 (negatif satu) pada kriteria. Indeks komposit positif +1 (positif satu) diartikan semakin tinggi indeks suatu kriteria maka keadaan kriteria tersebut semakin buruk dan semakin buruk keadaan suatu daerah. Sebaliknya, indeks komposit negatif -1 (negatif satu) diartikan semakin rendah indeks suatu kriteria maka keadaan kriteria tersebut semakin baik dan semakin baik keadaan suatu daerah. Indeks Komposit adalah penjumlahan nilai indikator yang dihitung untuk penentuan Daerah Tertinggal. KemenDPDTT juga menetapkan bobot variabel yang akan digunakan untuk menghitung indeks komposit.

\section{Indeks Pembangunan Desa (IPD)}

Untuk menggambarkan tingkat kemajuan desa pada suatu waktu, Bappenas (2015), bekerjasama dengan BPS mengembangkan sistem pengukuran yang dengan apa yang disebut sebagai Indeks Pembangunan Desa. Indeks Pembangunan Desa (IPD) adalah indeks komposit yang disusun menggunakan beberapa dimensi, variabel, dan indikator kuantitatif. Unit analisisnya "Desa” menurut Undang-Undang No. 6 Tahun 2014 tentang Desa. Setiap desa memiliki nilai IPD. IPD disusun dengan 5 dimensi yang mencakup 12 variabel dan 42 indikator. 
Nilai IPD diperoleh dari penjumlahan secara tertimbang terhadap setiap Indikator penyusun IPD. Nilai yang dijumlahkan adalah skor setiap Indikator yang sudah ditimbang/dikalikan dengan bobot masing masing Indikator. Apabila IPD diukur secara berkala dan ditampilkan antar waktu, maka dapat diperoleh dinamika dan perubahan tingkat kemajuan desa. Dinamika dan perubahan tingkat kemajuan desa secara tidak langsung merupakan ukuran kinerja pembangunan di desa atau kawasan perdesaan (Bappenas, 2015).

\section{Badan Pusat Statistik (BPS)}

Badan Pusat Statistik adalah Lembaga Pemerintah Non Kementerian yang bertanggung jawab langsung kepada Presiden. Peranan BPS berdasarkan undang-undang Nomor 16 Tahun 1997 adalah menyediakan kebutuhan data bagi pemerintah dan masyarakat. Data ini didapatkan dari sensus atau survei yang dilakukan sendiri dan juga dari departemen atau lembaga pemerintahan lainnya sebagai data sekunder, membantu kegiatan statistik di kementrian, lembaga pemerintah atau institusi lainnya, dalam membangun sistem perstatistikan nasional, mengembangkan dan mempromosikan standar teknik dan metodologi statistik, dan menyediakan pelayanan pada bidang pendidikan dan pelatihan statistik, membangun kerjasama dengan institusi internasional dan negara lain untuk kepentingan perkembangan statistik Indonesia (BPS, 2019).

Pembangunan infrastruktur teknologi informasi di BPS didasarkan pada tujuan yang ingin dicapai yaitu mengikuti perkembangan permintaan dan kebutuhan dalam pengolahan data statistik; melakukan pembaharuan/inovasi dalam hal metode kerja yang lebih baik serta memberikan kemudahan kepada publik dalam mendapatkan informasi statistik (BPS, 2019).

\section{Google Maps}

Google Maps adalah layanan pemetaan web yang dikembang oleh google. Layanan ini dapat diakses melalui situs http://maps.google.com. Pada situs tersebut dapat dilihat informasi geografis pada hampir semua wilayah di bumi. Layanan ini interaktif, karena di dalamnya peta dapat digeser sesuai keinginan pengguna, mengubah tingkat zoom, serta mengubah tampilan peta (Tafa, et al, 2018).

Ada empat jenis peta yang tersedia dalam Maps JavaScript API, yaitu: roadmap yang menampilkan tampilan peta jalan standar, satelit yang menampilkan gambar satelit Google Earth, hibrida yang menampilkan campuran pandangan normal dan satelit, terrain yang menampilkan peta fisik berdasarkan informasi penampakan topografi (Google, 2019).

Berdasarkan jurnal “Analisis Tingkat Akurasi Global Positioning System Smartphone dalam Menentukan Titik Lokasi pada Google Map” (Tafa, et al, 2018) menunjukkan persen kesalahan dari hasil penelitian setelah diratarata sebesar $1.6165 \%$. Hal ini dapat diartikan juga bahwa berdasarkan hasil penelitian, tingkat akurasi dari Google Maps sebesar 100\% - 1.6165\% yaitu 98.3835\%. Google Maps digunakan untuk mendapatkan data-data yang tidak tersedia pada BPS seperti: jarak desa ke kantor kabupaten yang membawahi, jarak desa ke pelayanan kesehatan terdekat, dan rata-rata jarak desa ke pusat pelayanan pendidikan dasar.

\section{PENELITIAN TERDAHULU}

Berikut adalah penelitian terdahulu yang berhubungan dengan desa tertinggal:

\section{Planning Without Baseline Information: Delimination of Urban and Rural Settlements in Oe- Cusse Ambeno, Timor-Leste}

Pembatasan wilayah-wilayah kota dan desa ditetapkan berdasarkan serangkaian kriteria yang didukung dalam informasi dasar baseline seperti populasi penduduk, infrastruktur yang ada, dan keberadaan fasilitas publik. Namun, dalam situasi di mana semua informasi dasar yang diperlukan untuk menggunakan metode pembatasan saat ini tidak tersedia atau tidak sesuai, proses perencanaan dapat dikompromikan. Dalam situasi ini, perlu diciptakan metode alternatif yang memungkinkan pembatasan batas perkotaan dan pedesaan untuk menetapkan kondisi pembangunan sesuai dengan batas-batas ini dan memastikan pengembangan wilayah yang benar dan efisien (Amado, et al, 2018).

Makalah ini menyajikan dan membahas metode yang dikembangkan untuk penetapan batas perkotaan dan pedesaan dalam rencana regional untuk Oé-Cusse Ambeno di Timor-Leste. Metode ini menggunakan instrumen fotogrametri dimana semua pemukiman dipetakan menggunakan peta Orthophoto dan kemudian dikembangkan 
secara khusus untuk memungkinkan penetapan batas kota dalam konteks di mana informasi dasar paling kurang, situasi khas di sebagian besar negara berkembang. Kegiatan ini telah memanfaatkan sekelompok ahli dari bidang arsitektur, perencanaan wilayah, geografi, ilmu lingkungan, arsitektur landscape, teknik sipil, ekonomi, dan hukum, semua disiplin ilmu yang diperlukan untuk menginformasikan penerapan dan pembobotan masingmasing kriteria (Amado, et al, 2018).

\section{Penggunaan Geographically Weighted Regression-Kriging untuk Klasifikasi Desa Tertinggal}

Rata-rata pengeluaran rumah tangga per kapita sebagai salah satu indikator utama pengukuran kemiskinan sering dimodelkan sebagai fungsi regresi secara global. Artinya nilai koefisien regresi yang sama diaplikasikan pada seluruh lokasi geografis. Padahal asumsi ini tidak selalu valid karena perbedaan lokasi sangat mungkin menghasilkan prediksi model yang berbeda. Geographically Weighted Regression (GWR) sebagai suatu metode regresi lokal diusulkan untuk mengatasi data yang tidak stationer (non-stationarity) tersebut. Karena model ini memperhitungkan geografis atau lokasi sebagai penimbang dalam memprediksi parameter modelnya. Dengan menggabungkan data sensus dan survei dalam membangun model rata-rata pengeluaran rumah tangga per kapita, diharapkan dapat digunakan untuk memprediksi ukuran kemiskinan sampai tingkat administrasi terkecil (desa). Namun demikian tidak seperti regresi global yang dapat digunakan untuk memprediksi di setiap lokasi, model GWR tidak dapat digunakan untuk memprediksi di luar lokasi sampel penelitian, kecuali dengan memprediksi koefisien regresi di lokasi tersebut. Untuk mengatasi masalah ini maka dalam makalah ini diusulkan penggunaan prediktor Kriging. Prediksi rata-rata pengeluaran rumah tangga per kapita berdasarkan pendekatan GWR Kriging ini yang akan digunakan untuk mengklasifikasikan suatu desa tertinggal atau tidak tertinggal di seluruh Jawa Tengah, setelah dibandingkan dengan garis kemiskinan yang telah didefinsikan oleh BPS (Dimulyo, 2009).

\section{Defining Expansion Areas in Small Urban Settlements - An Application to The Municipality of Tomar (Portugal)}

Konsumsi yang cepat dan terus meningkat dari daerah pedesaan secara negatif mempengaruhi layanan terkait ekosistem, termasuk produksi makanan, pengaturan energi, pasokan air, pasokan ruang rekreasi, keanekaragaman hayati dan nilai-nilai estetika alami, pada akhirnya berdampak pada kualitas hidup secara keseluruhan. Pendudukan yang tersebar juga merupakan masalah yang biasa terjadi di banyak bagian wilayah Portugal, dimana urbanisasi tumbuh meskipun populasinya semakin menurun. Hal ini dapat dikaitkan dengan beberapa faktor budaya, sosial dan ekonomi seperti pengurangan ukuran rumah tangga, peningkatan luas lantai per penduduk, preferensi untuk rumah keluarga tunggal dan bahkan untuk rumah liburan, yang semuanya terkait dengan kenaikan pendapatan keluarga, dan harga tanah yang lebih rendah di daerah pedesaan, di antara faktorfaktor lain (Ferreira and Condessa, 2012).

Salah satu tujuan rencana pengembangan kota di Portugal adalah untuk menentukan area ekspansi permukiman. Untuk tujuan ini penelitian dimulai dengan mendefinisikan metodologi yang memungkinkan untuk mengidentifikasi area perkotaan. Penelitian ini mendefinisikan metodologi untuk mengukur area ekspansi yang akan dialokasikan ke setiap pusat kota sesuai dengan parameter yang mencakup antara lain, ukuran dan posisi hirarkinya. Penelitian ini menggunakan metode pemetaan untuk melihat area mana yang dapat di ekspansi dengan faktor pembatas yang dianggap penting untuk penelitian ini(Ferreira and Condessa, 2012).

\section{METODE PENELITIAN}

\section{Penetapan Variabel Desa Tertinggal}

Dalam menetapkan variabel penetapan desa tertinggal, digunakan tabulasi untuk memudahkan pemilihan faktorfaktor penetapan desa tertinggal dari penelitian terdahulu seperti tabel 1 dan tabel 2.

Tabel 1. Contoh tabulasi pemilihan faktor penetapan menjadi variabel pilihan

\begin{tabular}{ccc}
$\begin{array}{c}\text { Penelitian terdahulu, } \\
\text { Pengarang, Tahun }\end{array}$ & $\begin{array}{c}\text { Faktor penetapan desa } \\
\text { tertinggal }\end{array}$ & Variabel \\
\hline Jurnal 1 & \\
\hline Jurnal 2 & \\
\hline
\end{tabular}


Tabel 2. Contoh tabulasi pemilihan variabel penetapan desa tertinggal

\begin{tabular}{llllll} 
No & Variabel & Bappenas & Jurnal 1 & Jurnal 2 & Jurnal 3 \\
\hline 1. & Variabel terpilih 1 & & & \\
\hline 2. & Variabel terpilih 2 & & &
\end{tabular}

Tabel 1 dan 2 dipakai untuk memilih variabel penetapan desa tertinggal dengan variabel Kemen DPDTT sebagai patokan yang direduksi dengan variabel dari jurnal lain dengan syarat memiliki variabel yang sama atau terkait pada jurnal 1 sebagai jurnal utama dan minimal satu jurnal lainnya sebagai jurnal pendukung.

\section{Penetapkan Data Sampel Populasi Desa}

Pada penelitian ini sampel yang akan dihitung dengan model yang dikembangkan disebut populasi I. Sampel populasi I ditetapkan dengan melihat desa yang dinyatakan tertinggal oleh Direktorat Jendral Pembangunan Daerah Tertentu (Ditjen PDTu).

Proses pengumpulan data-data yang digunakan dalam pengisian variabel berasal dari BPS (Badan Pusat statistik) yaitu Statistik Kesejahteraan per provinsi, Satistik Perumahan per provinsi, provinsi daerah dalam Angka, Statistik Potensi Desa per provinsi sesuai tahun keluarnya dan Google Maps yang dapat diakses melalui situs http://maps.google.com. Data yang digunakan untuk penetapan desa tertinggal diasumsikan menggunakan data kabupaten yang membawahi. Sedangkan Google Maps digunakan dengan mengacu pada jurnal "Planning Without Baseline Information: Delimination of Urban and Rural Settlements in Oe-Cusse Ambeno, Timor-Leste" yang menggunakan instrumen fotogrametri dalam mendapatkan data yang tidak tersedia secara langsung. Tetapi, dikarenakan fotogrametri itu sendiri tidak mudah didapatkan maka, pada penelitian ini menggunakan Google Maps untuk mendapatkan data-data yang tidak tersedia pada BPS dengan mengukur jarak dari titik tengah sebuah desa ke tujuan yang ingin diukur jaraknya seperti: jarak desa ke kantor kabupaten yang membawahi, jarak desa ke pelayanan kesehatan terdekat, dan rata-rata jarak desa ke pusat pelayanan pendidikan dasar. Datadata yang terlah terkumpul akan diisi ke dalam tabel seperti di bawah ini.

Tabel 3. Contoh pengisian data per variabel

\begin{tabular}{llll} 
No & Variabel & Data & Satuan \\
\hline 1. & Variabel terpilih 1 & \\
\hline 2. & Variabel terpilih 2 &
\end{tabular}

\section{Menghitung Rata-Rata Indeks Desa Teringgal}

Rata-rata indeks desa tertinggal untuk populasi I memerlukan indeks bobot untuk menghitung rata-rata indeks desa tertinggalnya. Indeks bobot variabel yang digunakan pada skripsi ini adalah berasal dari Peraturan Menteri Desa, Pembangunan Daerah Tertinggal, dan Transmigrasi Republik Indonesia nomor 3 Tahun 2016 tetang petunjuk teknik penentuan indikator dalam penentuan daerah tertinggal secara nasional yang kemudian dikonversi agar total bobot berjumlah $100 \%$.

Setelah data-data yang dikumpulkan telah terisi dan penetapan bobot selesai, maka akan dilakukan perhitungan rata-rata indeks desa tertinggal dengan cara:

1. Perhitungan indeks dihitung menggunakan rumus:

$$
\text { indeks = nilai variabel } x \text { indeks bobot }
$$

2. Rata-rata indeks dihitung menggunakan rumus:

$$
\text { rata }- \text { rata indeks }=\frac{\text { Enilai indeks }}{\text { jumlah variabel }}
$$

3. Rata-rata total indeks dihitung menggunakan rumus:

$$
\text { rata }- \text { rata total indeks }=\frac{\text { Erata-rata indeks desa }}{\text { jumlah sampel }}
$$

Nilai positif (+) pada rata-rata indeks berarti daerah menuju ke arah tertinggal. Sebaliknya juga, jika nilai menunjukkan negatif (-) pada rata-rata indeks maka daerah menuju ke arah tidak tertinggal. Setelah dilakukan perhitungan nilai rata-rata indeks desa, kemudian dilanjutkan dengan uji hipotesis sampel-ganda. Namun, 
sebelum melakukan hipotesis sampel-ganda harus dilakukan terlebih dahulu uji normalitas yang menunjukkan populasi terdistribusi normal.

\section{Uji Normalitas}

Pada penelitian ini, akan digunakan uji normalitas Shapiro Wilk. Uji Shapiro Wilk adalah sebuah metode atau rumus perhitungan sebaran data yang dibuat oleh shapiro dan wilk. Metode shapiro wilk adalah metode uji normalitas yang efektif dan valid digunakan untuk sampel berjumlah kecil. Dalam penerapannya, para peneliti dapat menggunakan aplikasi statistik yaitu: SPSS dan STATA. (Hidayat, 2017).

Cara baca hasil perhitungan uji normalitas Shapiro Wilk adalah dengan melihat nilai Shapiro Wilk hitung dan tingkat signifikansinya. Dalam hasil uji SPSS, nilai hitung Shapiro Wilk ditunjukkan dengan nilai value, sedangkan signifikansinya ditunjukkan dengan nilai Sig. Dasar pengambilan keputusan pada output dari uji normalitas Shapiro Wilk dengan SPSS teradapat sebagai berikut (Hidayat, 2017):

- jika nilai signifikansi kurang dari 0.05, maka kesimpulannya data tidak berdistribusi normal

- jika nilai signifikansi lebih dari 0.05, maka data tersebut berdistribusi normal.

Setelah uji normalitas dilakukan dan hasil menunjukkan bahwa kedua populasi terdistribusi normal, maka dapat dilanjutkan ke langkah selanjutnya yaitu uji hipotesis dengan sampel-ganda.

\section{Uji Hipotesis Mean Sampel Ganda}

Pada uji hipotesis, hal penting yang harus diperhatikan adalah bahwa pengujian hipotesis sampel-ganda ini bukan untuk mengestimasi nilai-nilai mutlak dari parameter-parameter yang ditinjau, melainkan untuk mengetahui nilai relatif dari parameter-parameter tersebut. Jadi tujuan dari uji hipotesis sampel-ganda adalah untuk menggunakan data dari dua sampel yang diperoleh dari dua populasi dan mengetahui apakah ada perbedaan yang secara statistik cukup berarti (significant) antara parameter-parameter dari kedua populasi tersebut (Harinaldi, 2005). Uji yang paling sesuai untuk digunakan dalam penelitian ini adalah Uji Hipotesis Mean dengan Sampel-Ganda yaitu Uji Independen sampel dengan uji t. Langkah-langkah melakukan uji ini adalah sebagai berikut. Sebelum dilakukan uji F atas varians, varians sampel kedua populasi harus diketahui terlebih dahulu. Menghitung varians sampel dengan rumus:

$$
s=\sqrt{\frac{\sum(x-\bar{x})^{2}}{n-1}}
$$

Dimana, $\overline{\mathrm{x}}=$ Mean dari sampel acak, $\mathrm{n}=$ jumlah sampel

1. Uji $F$ atas varians (Levine, et al, 2011):

a. Menghitung derajat kebebasan $(d f)$ dengan rumus:

$$
\begin{aligned}
& d f_{1}(\text { pembilang })=v_{1}=n_{1}-1 \\
& d f_{2}(\text { penyebut })=v_{2}=n_{2}-1
\end{aligned}
$$

dimana, $n_{1}$ = jumlah sampel populasi varians terbesar, $n_{2}=$ jumlah sampel populasi varians terkecil

b. Perhitungan rasio uji (RU) dengan menggunakan rumus:

$$
R U_{F}=F_{\text {test }}=\frac{s_{1}^{2}}{s_{2}^{2}}
$$

Dimana, $s_{1}=$ nilai standar deviasi terbesar populasi, $s_{2}=$ nilai standar deviasi terkecil populasi

2. Uji $t$ (Welch, 1947):

a. Menghitung derajat kebebasan $(d f)$ dengan rumus:

$$
d f=v=\frac{\left(\frac{s_{1}^{2}}{n_{1}}+\frac{s_{2}^{2}}{n_{2}}\right)^{2}}{\frac{s_{1}^{4}}{n_{1}^{2} v_{1}}+\frac{s_{2}^{4}}{n_{2}^{2} v_{2}}}
$$

Keterangan:

$v_{1}=n_{1}-1, v_{2}=n_{2}-1, n_{1}=$ jumlah sampel populasi $1, n_{2}=$ jumlah sampel populasi 2

b. Pernyataan aturan keputusan (Decision Rule)

c. Perhitungan rasio uji (RU) dengan menggunakan rumus:

$$
R U_{t}=\frac{\bar{x}_{1}-\bar{x}_{2}}{\sqrt{\frac{s_{1}^{2}}{n_{1}}+\frac{s_{2}^{2}}{n_{2}}}}
$$


Jika pada hasil uji hipotesis sampel-ganda dinyatakan bahwa populasi I tidak berbeda dengan populasi II, maka dapat ditarik keseimpulan bahwa model perhitungan dapat dipakai untuk penetapan desa tertinggal. Setelah uji hipotesis selanjutnya dihitung estimasi interval mean untuk populasi I.

\section{Estimasi Interval Mean dengan Distribusi-t}

Pada penelitian ini jenis estimasi interval mean populasi yang paling sesuai adalah menggunakan distribusi-t. Distribusi- $t$ adalah distribusi dengan sebuah parameter derajat kebebasan $n$. Distribusi ini digunakan karena jumlah sampel kecil $(\mathrm{n}<30)$ dan deviasi standard dari populasi tidak diketahui (Lapin, 1983).

Keterangan:

$$
\bar{x}-t_{\frac{\alpha}{2}, v} \sigma \bar{x}<\mu_{x}<\bar{x}+t_{\frac{\alpha}{2}, v} \sigma \bar{x}
$$

$\mu_{x}=$ mean populasi

$t_{\frac{\alpha}{2}}=$ nilai kritis $t$ yang tergantung pada tingkat kepercayaan dan derajat kebebasan (didapat dari tabel distribusi- $t$ )

$\sigma_{\bar{x}}=$ error standar dari mean

$\alpha=1$ - tingkat kepercayaan (sering disebut chance of error)

$v \quad=$ derajat kebebasan $(d f)=n-1$

Dalam situasi dimana deviasi standar populasi tidak diketahui, maka deviasi standar populasi harus diestimasi juga bersama-sama dengan mean populasinya. Estimator deviasi standar populasi adalah deviasi standar sampel (varians sampel) yang dapat dihitung menggunakan rumus 4 yang kemudian akan dipakai dalam perhitungan error standar sehingga error standar dapat diestimasikan menggunakan rumus 11.

$$
\sigma_{\bar{x}}=\frac{s}{\sqrt{n}}
$$

Setelah eror standar dihitung, selanjutnya masukkan ke dalam estimasi interval (10), maka akan didapatkan estimasi interval mean untuk desa tertinggal.

\section{HASIL ANALISIS DESA TERTINGGAL}

\section{Variabel Penetapan Desa Tertinggal}

Variabel akhir yang digunakan dalam penetapan desa tertinggal pada penelitian ini tertulis dalam tabel 4.

Tabel 4. Variabel penetapan desa tertinggal dan bobot per variabel

\begin{tabular}{llc} 
No & \multicolumn{1}{c}{ Variabel } & Bobot \\
\hline 1. & Persentase desa dengan jenis permukaan jalan utama terluas aspal/beton & -0.05809 \\
\hline 2. & Persentase desa dengan jenis permukaan jalan utama terluas diperkeras & 0.05809 \\
\hline 3. & Persentase desa dengan jenis permukaan jalan utama terluas tanah & 0.05809 \\
\hline 4. & Persentase desa dengan jenis permukaan jalan utama terluas lainnya & -0.05809 \\
\hline 5. & Persentase rumah tangga pengguna listrik & -0.07746 \\
\hline 6. & Persentase rumah tangga pengguna air bersih & -0.07746 \\
\hline 7. & Persentase desa yang mempunyai pasar tanpa bangunan permanen/semi permanen & 0.07746 \\
\hline 8. & Jumlah sarana dan prasarana kesehatan per 1000 penduduk & -0.07746 \\
\hline 9. & Ratio murid dan guru SD & 0.07746 \\
\hline 10. & Ratio murid dan guru SMP & 0.07746 \\
\hline 11. & Jarak dari desa ke kantor kabupaten yang membawahi & 0.25949 \\
\hline 12. & Jarak desa ke pelayanan kesehatan terdekat & 0.25949 \\
\hline 13. & Rata-rata jarak dari desa ke pusat pelayanan pendidikan dasar & 0.25949 \\
\hline 14. & Persentase desa tanah longsor per kabupaten & 0.05538 \\
\hline 15. & Presentase desa banjir per kabupaten & 0.05538 \\
\hline 16. & Persentase desa bencana lainnya per kabupaten & 0.05538 \\
\hline 17. & Persentase desa di kawasan hutan per kabupaten & 0.05538 \\
\hline & & $\mathbf{1}$
\end{tabular}

\section{Rata-Rata Indeks Desa Teringgal}

Hasil rata-rata indeks desa tertinggal dari sampel populasi desa yang dilakukan model penyederhanaan variabel (populasi 1) dapat dilihat pada tabel 5. Rata-rata indeks desa tertinggal sesuai IDM yang dijadikan patokan validasi (populasi 2) dapat dilihat pada tabel 6 . 
Tabel 5. Hasil rata-rata indeks per desa

\begin{tabular}{clc} 
No & \multicolumn{1}{c}{ Nama Desa } & Rata-rata indeks \\
\hline 1. & Desa Tubuhue, kabupaten Timor Tengah Selatan, NTT & 0.469 \\
\hline 2. & Desa Landau Buaya, kabupaten Sintang, Kalimantan Barat & 1.831 \\
\hline 3. & Desa Suebela, kabupaten Rote Ndao, NTT & 0.768 \\
\hline 4. & Desa Lamea, kabupaten Malaka, NTT & 0.853 \\
\hline 5. & Desa Sendoyan, kabupaten Sambas, Kalimantan Barat & 1.005 \\
\hline 6. & Desa Baturaja, kabupaten Pesisir Barat, Lampung & 0.396 \\
\hline 7. & Desa Lanosangia, kabupaten Buton Utara, Sulawesi Tenggara & 1.586 \\
\hline 8. & Kelurahan Bon Kawir, kabupaten Raja Ampat, Papua Barat & 0.172 \\
\hline 9. & Desa Arsopura, kabupaten Keerom, Papua & 0.712 \\
\hline 10. & Desa Batu Ampar, kabupaten Sumanep, Jawa Timur & -0.243 \\
\hline 11. & Desa Natah, kabupaten Gunung Kidul, DI Yogyakarta & 0.132 \\
\hline 12. & Desa Siompin, kabupaten Aceh Singkil, Aceh & 0.651 \\
\hline 13. & Desa Tudi, kabupaten Gorontalo Utara, Gorontalo & 0.263 \\
\hline 14. & Desa Kaibus, kabupaten Sorong Selatan, Papua Barat & 0.056 \\
\hline 15. & Desa Tofuti, kabupaten Morowali, Sulawesi Tengah & -0.206 \\
\hline 16. & Desa Sambori, kabupaten Bima, NTB & 0.285 \\
\hline 17. & Desa Tanahwulan, kabupaten Bondowoso, Jawa Timur & -0.316 \\
\hline 18. & Desa Raerobo, kabupaten Sabu Rijua, NTT & 1.105 \\
\hline 19. & Desa Air Periukan, kabupaten Seluma, Bengkulu & 0.150 \\
\hline 20. & Desa Pawis, kabupaten Landak, Kalimantan Barat & 1.192 \\
\hline 21. & Desa Tabolang, kabupaten Mamuju Tengah, Sulawesi Barat & 0.351 \\
\hline 22. & Desa Pasiang, kabupaten Polewali Mandar, Sulawesi Barat & 0.041 \\
\hline 23. & Desa Kasumeia, kabupaten Konawe, Sulawesi Tenggara & 0.003 \\
\hline 24. & Desa Waimital, kabupaten Seram Bagian Barat, Maluku & 0.803 \\
\hline 25. & Desa Bululoe, kabupaten Jeneponto, Sulawesi Selatan & -0.595 \\
\hline 26. & Desa Hilisao'otoniha, kabupaten Nias Selatan, Sumatera Utara & 0.126 \\
\hline 27. & Desa Aik Prapa, kabupaten Lombok Timur, NTB & 0.175 \\
\hline & & $\mathbf{0 . 4 3 6}$ \\
\hline & & \\
\hline
\end{tabular}

Tabel 6. Data desa populasi II beserta nilai IDM

\begin{tabular}{rlc}
\multicolumn{1}{c}{ No } & \multicolumn{1}{c}{ Nama Desa } & IDM \\
\hline 1 & Desa Siala Gundi, kab. Tapanuli Selatan, Sumatera Utara & 0.5967 \\
\hline 2 & Desa Padang Xi Punggasa, kab. Pesisir Selatan, Sumatera Barat & 0.5930 \\
\hline 3 & Desa Jetak Kidul, kab. Pekalongan, Jawa Tengah & 0.5968 \\
\hline 4 & Desa Sumber Makmur, kab. Kotawaringin Timur, Kalimantan Tengah & 0.5964 \\
\hline 5 & Desa Pante Crung Tanjon, kab. Pidie, Aceh & 0.5962 \\
\hline 6 & Desa Salafen, kab. Raja Ampat, Papua Barat & 0.5935 \\
\hline 7 & Desa Tolok, kab. Minahasa, Sulawesi Utara & 0.5952 \\
\hline 8 & Desa Seppong, kab. Majene, Sulbar & 0.5974 \\
\hline 10 & Desa Beji, kab. Gunung Kidul, Di Yogyakarta & 0.5930 \\
\hline 11 & Desa Rojo, kab. Sigi, Sulteng & 0.5887 \\
\hline 12 & Desa Mukit Selanjut, kab. Indragiri Hulu, Riau & 0.5944 \\
\hline 13 & Desa Rama Indera, kab. Lampung Tengah, Lampung & 0.5937 \\
\hline 14 & Desa Kelapa Lima, kab. Pohuwato, Gorontalo & 0.5927 \\
\hline 15 & Desa Mekar Sekuntum, kab. Sambas, Kalimantan Barat & 0.5917 \\
\hline 16 & Desa Yasa Mulya, kab. Merauke, Papua & 0.5857 \\
\hline 17 & Desa Ngestiharjo, kab. Kulon Progo, D I Yogyakarta & 0.5959 \\
\hline 18 & Desa Lego, kab. Polewali Mandar, Sulawesi Barat & 0.5899 \\
\hline 19 & Desa Duablolong, kab. Flores Timur, Nusa Tenggara Timur & 0.5879 \\
\hline 20 & Desa Bungur, kab. Tapin, Kalimantan Selatan & 0.5872 \\
\hline & & 0.5858 \\
\hline
\end{tabular}




\section{Uji Normalitas}

\begin{tabular}{ll|l|l|r|r|r|r|r} 
& \multicolumn{3}{c}{ Tests of Normality } & \multicolumn{3}{c}{ Shapiro-Wilk } \\
& populasi & Statistic & df & Sig. & Statistic & df & Sig. \\
\hline hasil mean & Populasi 1 & .122 & 27 & $.200^{\star}$ & .963 & 27 & .438 \\
\cline { 2 - 10 } & populasi 2 & .164 & 20 & .167 & .907 & 20 & .056 \\
\hline
\end{tabular}

Gambar 1. Hasil uji normalitas (sumber: SPSS)

Dari hasil uji normalitas Shapiro Wilk menggunakan SPSS, didapat nilai signifikansi sebagai berikut:

- Populasi 1: $0.438>0.05$

- Populasi 2: $0.056>0.05$

Kedua populasi didapat nilai signifinaksi lebih dari 0.05 yang mengartikan bahwa populasi ini terdistribusi normal.

\section{Uji Hipotesis Mean Sampel Ganda}

Dalam penelitian ini digunakan Uji Independen Sampel dengan Uji t. Namun diperlukan juga uji F untuk memeriksa apakah varian dari kedua populasi sama atau tidak.

1. Uji varian F dengan Uji Levene’s

\begin{tabular}{ll|l|l|} 
& \multicolumn{2}{c}{$\begin{array}{c}\text { Levene's Test for Equality of } \\
\text { Variances }\end{array}$} \\
\hline hasil mean & $\begin{array}{l}\text { Equal variances } \\
\text { assumed }\end{array}$ & 36.223 & Sig. \\
\hline & $\begin{array}{l}\text { Equal variances not } \\
\text { assumed }\end{array}$ & & \\
\hline
\end{tabular}

Gambar 2. Hasil Uji Levene’s (Sumber: SPSS)

Pada gambar 2 didapat nilai signifikan pada tabel uji Levene's sebesar 0 , dan $0<0.05$ maka disimpulkan varian data tidak sama $\left(\sigma_{1}^{2} \neq \sigma_{2}{ }^{2}\right)$.

2. Uji Independen Sampel dengan Uji $t$

\begin{tabular}{cl|c|c|c}
\hline hasil mean & \multicolumn{1}{c}{$\mathrm{t}$} & $\mathrm{df}$ & Sig. (2-tailed) \\
\hline & $\begin{array}{l}\text { Equal variances } \\
\text { assumed }\end{array}$ & -1.216 & 45 & .230 \\
\cline { 2 - 5 } & $\begin{array}{l}\text { Equal variances not } \\
\text { assumed }\end{array}$ & -1.417 & 26.003 & .168 \\
\hline
\end{tabular}

Gambar 3. Hasil uji sampel independen (Sumber: SPSS)

Pada uji $\mathrm{F}$ varian menunjukkan bahwa $\sigma_{1}{ }^{2} \neq \sigma_{2}{ }^{2}$, maka hasil yang dilihat pada tabel output Uji Sampel Independen adalah equal varians not assumed, yaitu 0.168 . Karena $0.168>0.05$ maka diambil hipotesis nol. Ini berarti mean rata-rata dari kedua sampel populasi tersebut tidak memiliki perbedaan yang signifikan dalam arti lain model penetapan desa tertinggal yang telah disederhanakan ini dapat digunakan dalam menentukan kualifikasi desa tertinggal.

\section{Estimasi Interval Mean dengan Distribusi-t}

Estimasi Interval yang dihitung merupakan estimasi interval dari populasi 1. Karena deviasi standar populasi tidak diketahui, maka deviasi standar populasi harus diestimasi juga bersama-sama dengan mean populasinya. Estimator deviasi standar populasi adalah deviasi standar sampel (s) yang kemudian akan dipakai untuk menghitung error standar. Hasil estimasi mean populasi, didapat bahwa mean dari desa tertinggal dengan model perhitungan yang telah disederhanakan berkisar diantara 0.2081 dan $0.6634\left(0.2081<\mu_{x}<0.6634\right)$. 


\section{KESIMPULAN}

Berdasarkan hasil penelitian ini, dapat ditarik kesimpulan sebagai berikut:

1. Berdasarkan uji hipotesis menunjukkan bahwa model penetapan desa tertinggal yang telah disederhanakan ini dapat digunakan dalam menentukan kualifikasi desa tertinggal.

2. Dari hasil estimasi mean populasi, didapat bahwa mean dari desa tertinggal dengan model perhitungan yang telah disederhanakan berkisar diantara 0.2081 dan 0.6634.

3. Dari sampel populasi I yang termasuk dalam desa tertinggal sesuai dengan model perhitungan ini adalah: Desa Tubuhue, kabupaten Timor Tengah Selatan, NTT , Desa Baturaja, kabupaten Pesisir Barat, Lampung, Kelurahan Bon Kawir, kabupaten Raja Ampat, Papua Barat, Desa Tudi, kabupaten Gorontalo Utara, Gorontalo, Desa Sambori, kabupaten Bima, NTB, Desa Tabolang, kabupaten Mamuju Tengah, Sulawesi Barat

4. Untuk desa yang nilai indeks rata-ratanya di bawah interval dapat diartikan juga sebagai desa berkembang atau desa maju dan untuk desa yang nilai indeks rata-ratanya di atas interval dapat diartikan juga sebagai desa sangat tertinggal.

\section{DAFTAR PUSTAKA}

Amando, A. R., et al. (2018). "Planning Without Baseline Information: Delimination of Urban and Rural Settlements in Oe-Cusse Ambeno, Timor-Leste”. J. Urban Planning, ASCE, Vol. 144, No. 3

Badan Pusat Statistik. Informasi Umum Tentang BPS. Tersedia di www: https://www.bps.go.id/menu/1/informasi-umum.html\#masterMenuTab1, (16 Juni 2019).

Bappenas. Modul Penghitungan Indeks Pembangunan Desa (IPD). Jakarta, 2015.

Dimulyo, S. (2009). "Penggunaan Geographically Weighted Regression-Kriging untuk Klasifikasi Desa Tertinggal”. SNATI 2009, Yogyakarta, 20 Juni 2009, 1907-5022

Ferreira, J. A. dan B. Condessa. (2012). "Defining expansion areas in small urban settlements - An application to the municipality of Tomar (Portugal)”. J. Urban Planning, Elsevier, Vol. 107 No. 03, 283-292.

Google. Maps JavaScript API. Tersedia di www: https://developers.google.com/maps/documentation/javascript/ maptypes\#MapCoordinates (16 Juni 2019).

Harinaldi. (2005). Prinsip-Prinsip Statistik untuk Teknik dan Sains. Erlangga, Jakarta

Hendrickson, Chris. Construction Planning. Tersedia di www: http://www.cmu.edu/cee/projects/PMbook/09_ Construction_Planning.html (04 Maret 2019).

Hidayat, A. Tutorial Uji Normalitas dengan SPSS Lengkap. Tersedia di www: https://www.statistikian.com/ 2013/02/uji-normalitas-pada-spss.html (17 Juni 2019).

Hidayat, A. Pengertian Dan Rumus Uji Saphiro Wilk - Cara Hitung. https://www.statistikian.com/2013/01/saphiro-wilk.html/amp (17 Juni 2019).

Kemen-DPDTT. (2016). Peraturan Menteri Desa, Pembangunan Daerah Tertinggal dan Transmigrasi Republik Indonesia Nomor 3 Tahun 2016 Tentang Petunjuk Teknis Penentuan Indikator Penetapan Daerah Tertinggal Secara Nasional.

Kemen-DPDTT. (2018). Peraturan Menteri Desa, Pembangunan Daerah Tertinggal dan Transmigrasi Republik Indonesia Nomor 16 Tahun 2018 Tentang Prioritas Penggunaan Dana Desa Tahun 2019.

Lapin, L. L. (1983). Probability and Statistic for Modern Engineering.Wadsworth, Inc., California

Levine, D. M., et al. (2011). Statistics for Managers Using Microsoft Excel Sixth Edition. Pearson Education, New Jersey

Priadi, S. Pembangunan Infrastruktur Daerah Tertinggal. Tersedia di www: http://kulitdjeruk.blogspot.com/ 2016/02/pembangunan-infrastruktur-daerah.html (03 Maret 2019).

Santoso, Singgih. (2001). “SPSS versi 10 Mengolah Data Statistik Secara Profesional”. PT. Elex Media Komputindo, Jakarta

Tafa, I. A., D. Suryadi, dan T. Pontia. (2018). “Analisis Tingkat Akurasi Global Positioning System Smartphone dalam Menentukan Titik Lokasi pada Google Map”. Jurnal Elektro, Universitas Tanjungpura

Welch, B. L. (1947). “The Generalization Of 'Student's' Problem When Several Different Population Variances Are Involved”. Jurnal Biometrika, 34(1-2), 28-35. 